\title{
Aktivitas Lactobacillus plantarum Isolat Air Susu Ibu pada Tikus Galur Wistar Diabetes Mellitus
}

\author{
Oktavia Kartikasari ${ }^{1}$, Anggun Dian Astuti $^{2}$, Mega Berkah Mustika Wabula ${ }^{3}$, Sri Sinto Dewi ${ }^{4}$ \\ ${ }_{1,2,3}$ Fakultas Ilmu Keperawatan dan Kesehatan, Universitas Muhammadiyah Semarang, Indonesia \\ ${ }^{4}$ Laboratorium Mikrobiologi Analis Kesehatan, Universitas Muhammadiyah Semarang, Indonesia \\ Email: oktaviakartikasari19@gmail.com
}

\begin{abstract}
Activity of Lactobacillus plantarum Isolate Breast Milk in Diabetic Wistar Mice. Lactobacillus plantarum is a Lactic Acid Bacteria (LAB) that has the potential to be used as a probiotic agent. Probiotics are antidiabetic because they can inhibit alpha-glucosidase enzymes. This study aims to was to determine the antidiabetic effects of probiotic Lactobacillus plantarum isolates of breast milk (ASI). The study was conducted at the Microbiology Laboratory of the University of Muhammadiyah Semarang and the Pharmacology Laboratory of the Semarang College of Pharmacy during the month of April-June. Experimental research with 25 male wistar mice was divided into 5 groups (K-, K+, P1, P2, P3) Alloxan monohydrate induction was carried out intraperitoneally at a dose of $150 \mathrm{mg} / \mathrm{kg}$ BW. Fasting blood glucose measurements were performed at baseline (before alloxan induction), post alloxan and at the end of treatment. Diabetic mice fasting blood glucose levels should be $\pm 200 \mathrm{mg} / \mathrm{dL}$. Suspension of Lactobacillus plantarum isolate ASI was carried out orally for 7 days. Based on the ANOVA test there were significant differences in the decrease in blood glucose with a significant value of $p$ value $=0,009<0,05$. Based on the Tuckey post hoc test treatment group P1, P2, P3 there were no significant differences between treatment groups even though the dosage was different. 1 time a day treatment is an efficient dose in reducing blood glucose.
\end{abstract}

Keywords: Antidiabetic, Breast Milk, Diabetes Mellitus, LAB, Lactobacillus plantarum

\begin{abstract}
Abstrak: Aktivitas Lactobacillus plantarum Isolat Air Susu Ibu pada Tikus Galur Wistar Diabetes Mellitus. Lactobacillus plantarum adalah Bakteri Asam Laktat (BAL) yang berpotensi digunakan sebagai agen probiotik. Probiotik sebagai antidiabetes karena mempunyai kemampuan untuk menghambat enzim alpha glukosidase. Penelitian ini bertujuan untuk mengetahui efek antidiabetes dari probiotik Lactobacillus plantarum isolat Air Susu Ibu (ASI). Penelitian dilakukan di Laboratorium Mikrobiologi Universitas Muhammadiyah Semarang dan Laboratorium Farmakologi Sekolah Tinggi Ilmu Farmasi Semarang selama bulan April-Juni. Penelitian secara Eksperimen dengan 25 ekor tikus wistar jantan dibagi menjadi 5 kelompok (K-, K+, P1, P2, P3). Induksi aloksan monohidrat dilakukan pada hewan uji secara intraperitoneal dengan dosis $150 \mathrm{mg} / \mathrm{Kg} \mathrm{BB}$. Pengukuran glukosa darah puasa dilakukan pada awal (sebelum induksi aloksan), post aloksan dan akhir perlakuan. Tikus diabetes kadar glukosa darah puasa $\pm 200 \mathrm{mg} / \mathrm{dL}$. Pemberian suspensi Lactobacillus plantarum isolat ASI dilakuan secara oral dengan sounde pada hewan uji selama 7 hari. Berdasarkan uji ANOVA terdapat perbedaan bermakna terhadap penurunan glukosa darah dengan nilai signifikan $p$-value $=0,009<0,05$. Berdasarkan uji post hoc Tuckey kelompok perlakuan P1, P2, P3 tidak terdapat perbedaan bermakna antar kelompok perlakuan walaupun dosisnya berbeda. Pemberian 1 kali sehari merupakan dosis yang efisien dalam menurunkan glukosa darah.
\end{abstract}

Kata kunci: Antidiabetes, Isolat Air Susu Ibu, Diabetes Mellitus, BAL, Lactobacillus plantarum

\section{PENDAHULUAN}

World Health Organization (WHO) tahun 2016, mendefinisikan Diabetes Mellitus (DM) atau disebut diabetes merupakan penyakit gangguan metabolisme menahun akibat sel $\beta$ pankreas tidak memproduksi cukup insulin atau tubuh tidak dapat menggunakan insulin yang diproduksi secara efektif. Insulin adalah hormon yang mengatur keseimbangan kadar gula darah akibat terjadi peningkatan konsentrasi glukosa di dalam darah hiperglikemi. DM tipe 1 atau yang dulu dikenal dengan nama Insulin Dependent Diabetes Mellitus (IDDM), terjadi karena kerusakan sel $\beta$ pankreas (reaksi autoimun). Sel $\beta$ pankreas merupakan satu-satunya sel tubuh yang 
menghasilkan insulin yang berfungsi untuk mengatur kadar glukosa dalam darah. Bila kerusakan sel $\beta$ pankreas telah mencapai $80-90 \%$ maka gejala Diabetes Mellitus mulai muncul. Perusakan sel ini lebih cepat terjadi pada anakanak dari pada dewasa. DM tipe 2 merupakan $90 \%$ dari kasus DM yang dulu dikenal sebagai Non Insulin Dependent Diabetes Mellitus (NIDDM). Bentuk DM ini bervariasi mulai yang dominan resistensi insulin, defisiensi insulin relatif sampai defek sekresi insulin. Pada diabetes ini terjadi penurunan kemampuan insulin bekerja dijaringan perifer (resistensi insulin) dan disfungsi sel $\beta$. Akibatnya, pankreas tidak mampu memproduksi insulin yang cukup untuk mengkompensasi resistensi insulin. Kedua hal ini menyebabkan terjadinya defisiensi insulin relatif (American Diabetes Association (ADA), 2011).

Indonesia menempati peringkat ke tujuh di dunia untuk prevalensi penderita diabetes bersama dengan China, India, Amerika Serikat, Brazil, Rusia, dan Meksiko dengan jumlah estimasi orang dengan diabetes sebesar 10 juta (Atlas, 2015).

Obat antidiabetes yang beredar saat ini cukup banyak dan bervariasi, namun terapi dengan pengobatan sintetis sering menemui kegagalan antara lain disebabkan resistensi terapi, efek samping, dan biaya yang tinggi akibat pengobatan jangka panjang (Marianne et al., 2014). Obat yang sering digunakan dalam pengobatan farmakologis pada penyakit diabetes adalah Metformin, Sulfonilurea, Pioglitazone Gliptin (penghambat DPP-4) Penghambat SGLT2, Agonis GLP-1, Acarbose dan lain-lain. Pengendalian diabetes dan penurunan kadar glukosa darah dapat menggunakan probiotik (Lye et al., 2009). Probiotik merupakan mikroorganisme berupa bakteri yang diberikan dalam takaran yang cukup memberikan manfaat kesehatan pada inangnya (Chen et al., 2014).

Bakteri Asam Laktat (BAL) berkontribusi besar memberikan manfaat fungsional bagi tubuh manusia sebagai probiotik. Bakteri asam laktat merupakan kelompok bakteri yang bersifat Gram positip, tidak berspora, tidak mempunyai sitokrom, aerotoleran, bersifat anaerobik hingga mikroaerofilik, berbentuk bulat atau batang yang menghasilkan asam laktat sebagai produk akhir metabolik utama selama fermentasi karbohidrat, $\mathrm{H} 2 \mathrm{O} 2$, antimkroba dan anti kanker. Bakteri asam laktat mampu bertahan dalam saluran pencernaan dapat memberikan kontribusi terhadap kesehatan (Januarsyah, 2007).

Bakteri asam laktat atau probiotik mempunyai afinitas pengikatan yang tinggi terhadap membran sel epitel mukosa dan dapat bertindak sebagai pembawa antigen, serta mengikatkan ke jaringan target sehingga dapat mengaktivasi makrofag untuk membangkitkan respon imun mukosa yang dapat diketahui dengan munculnya IgA (Dewi dan Herlisa, 2015).

BAL memiliki potensi sebagai kandidat probiotik dengan beberapa syarat yang harus dipenuhi yaitu stabil terhadap asam (terutama asam lambung), stabil terhadap garam empedu dan mampu bertahan hidup selama berada pada bagian atas usus kecil, memproduksi senyawa antimikroba antimikroba antara lain asam-asam organik, hidrogen peroksida dan bakteriosin, mampu menempel dan mengkolonisasi sel usus manusia, tumbuh baik dan berkembang dalam saluran pencernaan, aman digunakan oleh manusia dan koagregasi membentuk lingkungan mikroflora yang normal dan seimbang (Fatmawati, 2013).

Terdapat beberapa mekanisme terkait sifat fungsional probiotik sebagai antidiabetes. Beberapa strain probiotik mampu mengurangi stres oksidatif pankreas yang menyebabkan peradangan kronis dan apoptosis sel beta pankreas (Zhang dan Zhang 2013). Hal ini berhubungan dengan aktivitas antioksidan yang dimiliki oleh probiotik. Mekanisme lainnya dari probiotik sebagai antidiabetes adalah kemampuan untuk menghambat enzim alfa glukosidase (Ramchandran and Shah, 2008). Enzim alfa glukosidase adalah enzim yang berperan dalam pemecahan karbohidrat menjadi glukosa pada saluran pencernaan (Subroto, 2006). Enzim ini dapat meningkatkan kadar glukosa darah sehingga untuk mencegah naiknya glukosa darah maka dibutuhkan suatu inhibitor enzim alfa glukosidase.

Air susu ibu (ASI) merupakan makanan pertama dan terbaik yang diberikan untuk bayi, karena kandungan laktosa dan garam organik yang di sekresi oleh kelenjar mamae dari ibu laktasi. ASI mengandung faktor bifidogenik, suatu oligosakarida yang disebut asetil glukosamin dan glikoprotein yang dapat mendukung pertumbuhan BAL khususnya bifidobakteria (Salminen, et al., 2004). ASI mengandung zat gizi, hormon, faktor kekebalan tubuh, anti alergi, dan anti inflamasi. ASI mengandung hampir 200 unsur zat makanan (Purwanti, 2004). Air Susu Ibu (ASI) merupakan sumber nutrisi bagi bayi yang mengandung BAL (Setianingsih, 2010). Hasil isolasi dan identifikasi bakteri asam laktat dari ASI adalah Pediococcus acidilactic dan Lactobacillus plantarum, Lactobacillus acidophilus (Dewi and Ariyadi, 2017). 
Lactobacillus sp. merupakan genus terbesar dari kelompok BAL. Genus Lactobacillus bersifat Gram positif dan tidak membentuk spora, serta bersifat anaerob fakultatif. Lactobacillus sp. banyak terdapat pada produk makanan fermentasi seperti produkproduk susu fermentasi (yoghurt, keju, kefir) produk fermentasi daging seperti sosis fermentasi, serta produk fermentasi sayuran seperti pikel, kimchi, dan sauerkraut. Lactobacillus sp. berkontribusi untuk pengawetan, ketersediaan nutrisi, dan flavour pada produk fermentasi tersebut (Salminen dan Wright 2004).

Penelitian Djide (2008) mampu mengisolasi bakteri probiotik dari ASI yaitu genus Lactobacillus yang dapat berpotensi dapat menurunkan kolesterol. Air susu ibu berpotensi sebagai penghasil probiotik karena air susu ibu mengandung glikoprotein dan $N$ acetylglucosamin untuk pertumbuhan bakteri probiotik.

Genus Lactobacillus mempunyai beberapa kelebihan yang berpotensi untuk digunakan sebagai agen probiotik, diantaranya adalah mampu bertahan pada $\mathrm{pH}$ rendah, tahan terhadap garam empedu, memproduksi antimikrobia dan daya antagonistik terhadap patogen enterik, mampu mengasimilasi serum kolesterol dan mendekonjugasi garam empedu serta dapat tumbuh baik pada medium sederhana (Rahayu, 2001). Kemampuan mendekonjugasi garam empedu berhubungan dengan adanya aktivitas enzim Bile Salt Hydrolase (BSH) yang dihasilkan oleh bakteri tersebut (Fadhilah dkk, 2015).

Penelitian tentang pemanfaatan

Lactobacillus plantarum dari isolat ASI sebagai antidiabetes alami belum pernah dilakukan. Oleh karena itu perlu dilakukan penelitian untuk mengetahui aktivitas Lactobacillus plantarum dari isolat ASI sebagai salah satu solusi alternatif antidiabetes yang lebih menyehatkan dibandingkan dengan pengobatan sintetis sesuai dengan program pemerintah Gerakan Masyarakat Hidup Sehat (GERMAS).

\section{METODE}

Jenis penelitian adalah ekperimental dengan menggunakan rancangan acak lengkap (RAL) pola faktorial yang terdiri dari 5 kelompok dengan 5 kali ulangan. Penelitian ini dilakukan di Laboratorium Mikrobiologi Fakultas Ilmu Keperawatan dan Kesehatan Universitas Muhammadiyah Semarang dan di Laboratorium
Farmakologi (STIFAR) Semarang selama bulan April-Juni.

Alat digunakan dalam penelitian ini adalah alat-alat kaca, spektrofotometer, sonde oral, syringe $1 \mathrm{ml}$, neraca analitik, tabung kapiler, handscoon, masker. Bahan yang digunakan untuk penelitian ini adalah isolat Lactobacillus plantarum dari ASI yang diperoleh dari Laboratorium Mikrobiologi Universitas Muhammadiyah Semarang, tikus wistar jantan, pakan standart, aloksan monohidrat (Sigma Aldrich), $\mathrm{NaCl}$ fisiologis, MRSA (deMan Rogose Sharpe Agar), MRSB (deMan Rogose Sharpe Broth) dari OXOID, $\mathrm{CaCO} 31 \%$, satu kit reagen GOD-PAP dari Diagnosa Systems Internasional (DSI).

Isolat Lactobacillus plantarum dari ASI di inokulasikan ke dalam media MRSB secara aseptik dihomogenkan dengan cara digoyang dan diinkubasi selama 24 jam pada suhu $37^{\circ} \mathrm{C}$. Bakteri yang aktif ditandai dengan kekeruhan pada media MRSB. Pembuatan suspensi bakteri dengan cara pengambilan 3 sampai 5 koloni bakteri yang sudah teridentifikasi spesifik Lactobacillus plantarum pada media MRSA, kemudian dimasukkan ke dalam Nacl fisiologis sebanyak $5 \mathrm{ml}$ lalu dibandingkan dengan kekeruhan Mc Farland 1.

Penelitian ini menggunakan 25 ekor tikus wistar jantan umur 12-16 minggu dengan berat badan rata-rata 150-200gram yang telah tersertifikasi kemudian dibagi menjadi 5 kelompok dan masing-masing kelompok terdapat 5 ekor tikus. Kelima kelompok penelitian tersebut adalah K-: tanpa perlakuan/tikus sehat (kontrol negatif), $\mathrm{K}+$ : diinduksi aloksan/tikus DM (kontrol positif), P1: tikus DM dan diberi suspensi Lactobacillus plantarum dosis 1,0ml/ekor (dosis $1 \times 1$ kali sehari), P2: tikus DM dan diberi suspensi Lactobacillus plantarum dosis 1,0ml/ekor (dosis $1 \times 2$ kali sehari), P3: tikus DM dan diberi suspensi Lactobacillus plantarum dosis 1,0ml/ekor (dosis $1 \times 3$ kali sehari).

Induksi aloksan monohidrat dilakukan pada hewan uji secara intraperitoneal dengan dosis $150 \mathrm{mg} / \mathrm{Kg}$ BB setelah proses adaptasi selama 7 hari di laboratorium. Tikus yang digunakan adalah tikus diabetes dengan kadar glukosa darah puasa $\pm 200 \mathrm{mg} / \mathrm{dL}$.

Penelitian ini telah mendapatkan Ethical Clearance (No:233/KEPK FKM/UNIMUS/2019) dari Komisi Etik Penelitian Fakultas Kesehatan Masyarakat Universitas Muhammadiyah Semarang.

Tikus yang telah mengalami diabetes diberi Lactobacillus plantarum isolat ASI sesuai dengan dosis yang telah ditetapkan pada masing- 
masing kelompok. Pemberian isolat dilakukan secara oral selama 7 hari dengan interval waktu pemberian Lactobacillus plantarum 5 jam. Selama perlakuan tikus diberi makan dan minum secara ad libitum.

Pengukuran kadar glukosa darah menggunakan alat Spektrofotometer setelah tikus di puasakan selama 12 jam. Pengambilan sampel darah melalui vena mata. Darah di sentrifius dan diambil bagian supernatant (serum) kemudian di ukur glukosa darah dengan metode Glucose Oxidase-Phenol 4-Aminoantipirin (GOD-PAP). Kadar glukosa darah diperiksa pada awal (sebelum induksi aloksan), post aloksan dan akhir perlakuan.

Data hasil pengukuran glukosa yang diperoleh di analisis menggunakan uji ANOVA satu arah. Kemudian di lanjutkan dengan uji post hoc Tuckey untuk mengetahui perbedaan dari antar kelompok.

\section{HASIL}

Tabel 1 menunjukkan hasil rata-rata pengukuran kadar glukosa darah pada lima kelompok perlakuan. Terlihat variasi kenaikan dan penurunan kadar glukosa darah awal, post aloksan dan akhir perlakuan. Hal ini dikarenakan perbedaan respon yang dihasilkan dari masingmasing individu hewan percobaan terhadap kerusakan sel $\beta$ pankreas yang disebabkan oleh zat penginduksi diabetes, yang pada penelitian ini menggunakan zat diabetogenik aloksan monohidrat. Kisaran normal kadar glukosa darah mencit $<126 \mathrm{mg} / \mathrm{dL}$ (Malik, Nasrul and Asterina, 2014). Diabetes Mellitus ditandai dengan tingkat abnormal glukosa darah (Alsayadi et al., 2014)

Tabel 1. Hasil Rata-Rata Kadar Glukosa Darah Semua Kelompok Perlakuan Rata-Rata Kadar Glukosa Darah (mg/dL)

\begin{tabular}{lrrr} 
& \multicolumn{3}{c}{ Kelompok } \\
\cline { 2 - 4 } & $\begin{array}{c}\text { Awal } \\
\text { (Sebelum } \\
\text { aloksan) }\end{array}$ & $\begin{array}{c}\text { Post } \\
\text { Aloksan }\end{array}$ & $\begin{array}{c}\text { Akhir } \\
\text { Perlakuan }\end{array}$ \\
\hline K - & 92,60 & 95,60 & 95,80 \\
K + & 96,20 & 184,20 & 186,00 \\
P1 & 81,00 & 198,00 & 131,80 \\
P2 & 93,40 & 226,40 & 162,40 \\
P3 & 86,00 & 213,40 & 145,80 \\
\hline
\end{tabular}

Tabel 2. Hasil Uji ANOVA Kadar Glukosa Darah Akhir Perlakuan

\begin{tabular}{lcccrr}
\hline & $\begin{array}{c}\text { Sum of } \\
\text { Squares }\end{array}$ & Df & $\begin{array}{c}\text { Mean } \\
\text { Square }\end{array}$ & $F$ & Sig. \\
\hline $\begin{array}{l}\text { Between } \\
\text { Groups }\end{array}$ & 22886,160 & 4 & 5721,540 & $\begin{array}{r}4,50 \\
0\end{array}$ &, 009 \\
\hline $\begin{array}{l}\text { Within } \\
\text { Groups }\end{array}$ & 25431,600 & 20 & 1271,580 & & \\
\hline Total & 48317,760 & 24 & & & \\
\hline
\end{tabular}

Tabel 2 disajikan untuk mengetahui pengaruh pemberian Lactobacilus plantarum isolat ASI terhadap kadar glukosa. Sebelumnya telah dilakukan uji normalitas data Shapiro-Wilk $(p$-value $>0,05)$ dan uji homogenitas data (Levene's test) ( $p$-value $>0,05)$.

Tabel 3. Hasil Uji post hoc Tuckey Glukosa Darah Akhir Semua Kelompok Perlakuan

\begin{tabular}{|c|c|c|c|}
\hline No & $\begin{array}{l}\text { Kelompok } \\
\text { perlakuan }\end{array}$ & $\begin{array}{l}\text { Nilai } p \text { - } \\
\text { value }\end{array}$ & Arti \\
\hline 1. & $\mathrm{~K}-$ vs $\mathrm{K}+$ & 0,006 & Berbeda signifikan \\
\hline 2. & $\mathrm{~K}-$ vs P1 & 0,516 & $\begin{array}{l}\text { Berbeda tidak } \\
\text { signifikan }\end{array}$ \\
\hline 3. & $\mathrm{~K}-\mathrm{vs} \mathrm{P} 2$ & 0,054 & $\begin{array}{l}\text { Berbeda tidak } \\
\text { signifikan }\end{array}$ \\
\hline 4. & $\mathrm{~K}-\mathrm{vs} \mathrm{P} 3$ & 0,214 & $\begin{array}{l}\text { Berbeda tidak } \\
\text { signifikan }\end{array}$ \\
\hline 5. & $\mathrm{~K}+$ vs $\mathrm{P} 1$ & 0,155 & $\begin{array}{l}\text { Berbeda tidak } \\
\text { signifikan }\end{array}$ \\
\hline 6. & $\mathrm{~K}+$ vs $\mathrm{P} 2$ & 0,831 & $\begin{array}{l}\text { Berbeda tidak } \\
\text { signifikan }\end{array}$ \\
\hline 7. & $\mathrm{~K}+$ vs $\mathrm{P} 3$ & 0,410 & $\begin{array}{l}\text { Berbeda tidak } \\
\text { signifkan }\end{array}$ \\
\hline 8. & $\mathrm{P} 1$ vs $\mathrm{P} 2$ & 0,661 & $\begin{array}{l}\text { Berbeda tidak } \\
\text { signifikan }\end{array}$ \\
\hline 9. & $\mathrm{P} 2$ vs $\mathrm{P} 3$ & 0,970 & $\begin{array}{l}\text { Berbeda tidak } \\
\text { signifikan }\end{array}$ \\
\hline 10. & $\mathrm{P} 2$ vs $\mathrm{P} 3$ & 0,945 & $\begin{array}{l}\text { Berbeda tidak } \\
\text { signifikan }\end{array}$ \\
\hline
\end{tabular}

Tabel 3 disajikan untuk mempermudah analisa perbedaan tiap kelompok perlakuan.

\section{PEMBAHASAN}

Diabetes terjadi ketika tubuh tidak dapat memproduksi cukup hormon insulin atau tidak dapat menggunakan insulin secara efektif. Insulin. Penyakit Diabetes Mellitus dapat disebabkan oleh banyak faktor. Faktor tersebut diantaranya faktor genetik, infeksi oleh kuman, faktor nutrisi, zat diabetogenik, dan radikal bebas (stres oksidatif) (Alsayadi et al., 2014).

Kelompok perlakuan K- kadar glukosa darah tikus berada pada kisaran normal, hal ini 
dikarenakan pada perlakuan K- tidak diberikan perlakuan apapun selama proses perlakuan.

Induksi diabetes eksperimental pada mencit menggunakan bahan kimia secara selektif menghancurkan sel-sel beta untuk menginduksi diabetes pada tikus adalah aloksan dan streptozotocin. Namun, pada penelitian ini menggunakan aloksan. Aloksan merupakan senyawa hidrofilik dan tidak stabil. Aloksan dapat digunakan secara intravena, intraperitoneal dan subkutan. Dosis intravena yang digunakan biasanya $65 \mathrm{mg} / \mathrm{kg} \mathrm{BB}$, sedangkan intraperitoneal dan subkutan adalah 2-3 kalinya (Szkudelski, 2001). Aloksan secara cepat dapat mencapaI pankreas, aksinya diawali oleh pengambilan yang cepat oleh sel $\beta$ Langerhans. Pembentukan oksigen reaktif merupakan faktor utama pada kerusakan sel tersebut. Pembentukan oksigen reaktif diawali dengan proses reduksi aloksan dalam sel $\beta$ Langerhans. Aloksan mempunyai aktivitas tinggi terhadap senyawa seluler yang mengandung gugus $\mathrm{SH}$, glutation tereduksi (GSH), sistein dan senyawa sulfhidril terikat protein (misalnya SH-containing enzyme).

Hasil dari proses reduksi aloksan adalah asam dialurat, yang kemudian mengalami reoksidasi menjadi aloksan, menentukan siklus redoks untuk membangkitkan radikal superoksida. Reaksi antara aloksan dengan asam dialurat merupakan proses yang diperantarai oleh radikal aloksan intermediet (HA) dan pembentukan "compound 305". Radikal superoksida dapat membebaskan ion ferri dari ferinitin, dan mereduksi menjadi ion ferro. Selain itu, ion ferri juga dapat direduksi oleh radikal aloksan. Radikal superoksida mengalami dismutasi menjadi hidrogen peroksida, berjalan spontan dan kemungkinan dikatalisis oleh superoksida dismutase. Salah satu target dari oksigen reaktif adalah DNA pulau Langerhans pankreas. Kerusakan DNA tersebut menstimulasi poly ADP-ribosylation, proses yang terlibat pada DNA repair. Adanya ion ferro dan hidrogen peroksida membentuk radikal hidroksi yang sangat reaktif melalui reaksi fenton (Szkudelski, 2001; Walde, et al., 2002).

Kelompok perlakuan $\mathrm{K}+, \mathrm{P} 1, \mathrm{P} 2, \mathrm{P} 3$ mengalami peningkatan kadar glukosa darah secara signifikan setelah di induksi aloksan. Aloksan di dalam tubuh mengalami metabolisme oksidasi reduksi menghasilkan radikal bebas dan radikal aloksan. Radikal ini mengakibatkan kerusakan pada sel $\beta$ pankreas, pada pulau Langerhans terjadi pengurangan jumlah massa sel, beberapa pulau Langerhans mengalami kerusakan, ukurannya menjadi lebih kecil bahkan ada yang hancur dan menghilang (Szkudelski, 2001).

Kerusakan sel $\beta$ pankreas tersebut mengakibatkan ketidakmampuan menghasilkan hormon insulin sehingga terjadi penyakit diabetes yang ditandai dengan keadaan hiperglikemia. Hal ini sejalan dengan hasil penelitian Adewani (2008), menyatakan bahwa pemberian aloksan tanpa disertai dengan perlakuan yang dapat menurunkan kadar glukosa akan menyebabkan kadar glukosa darah tikus tetap tinggi.

Kelompok perlakuan P1, P2, P3 menunjukkan penurunan kadar glukosa darah setelah diberi Lactobacillus plantarum isolat ASI sesuai dosis masing-masing kelompok perlakuan namun masih berada diatas normal. Meskipun demikian, berdasarkan uji ANOVA satu arah dengan taraf signifikan 0,05 rata-rata kadar glukosa darah akhir perlakuan diperoleh nilai probabilitas sebesar 0,009 ( $p$-value $<0,05$ ), hal ini menunjukkan bahwa pemberian Lactobacillus plantarum setelah tikus mengalami diabetes berpengaruh signifikan terhadap rata-rata penurunan kadar glukosa darah tikus. Hal ini dikarenakan Lactobacillus plantarum mempunyai kemampuan untuk menghambat enzim alfa glukosidase. Berdasarkan penelitian Syafiqoh (2016) hasil analisis penghambatan enzim alfa glukosidase menunjukkan bahwa ekstrak media kultur L. plantarum SK(5) memiliki aktivitas inhibisi alfa glukosidase yang meningkat seiring dengan peningkatan konsentrasi.

Enzim alfa glukosidase adalah enzim yang berperan dalam pemecahan karbohidrat menjadi glukosa pada saluran pencernaan (Subroto, 2006). Enzim tersebut merupakan enzim kunci pada proses akhir pemecahan karbohidrat. Enzim alfa glukosidase mengkatalisis hidrolisis terminal residu glukosa non pereduksi yang berikatan alfa1,4 pada berbagai substrat dan dihasilkan alfa-Dglukosa. Alfa glukosidase menghidrolisis ikatan alfa-glikosidik pada oligosakarida dan alfa-Dglikosida (Gao et al., 2007). Pemecahan karbohidrat menjadi glukosa mengakibatkan kadar glukosa dalam darah penderita diabetes akan semakin tinggi sehingga kerja enzim alfa glukosidase ini dalam usus harus dihambat (Panwar et al., 2014). Bakteri golongan BAL dapat berperan sebagai penghambat enzim alfa glukosidase dan dapat menyebabkan terjadinya penurunan kadar glukosa darah (Jain and Saraf, 2010).

Selain dari peran penghambat enzim alfaglukosidase terdapat peran aktivitas antioksidan. Hal ini didukung oleh Zhang dan Zhang (2013) bahwa BAL mampu mengurangi stres oksidatif pankreas yang menyebabkan peradangan kronis 
dan apoptosis sel $\beta$ pankreas sehingga dapat mengurangi efek diabetes tipe 2 . Stres oksidatif merupakan penyebab dari berbagai macam penyakit kronis pada manusia. Stres oksidatif disebabkan oleh aktivitas dari reactive oxidative species (ROS) melalui proses oksidasi.

Antioksidan merupakan suatu inhibitor bagi radikal bebas. Radikal bebas adalah spesies yang tidak stabil karena memiliki elektron yang tidak berpasangan dan mencari pasangan elektron dalam makromolekul biologi. Protein, lipida, dan DNA dari sel manusia yang sehat merupakan sumber pasangan elektron yang baik. Sumber radikal bebas diantaranya hasil metabolisme, neutrofil, radiasi uv, polusi air dan udara, lemak makanan, bahan kimia berbahaya, dan asap rokok. Antioksidan yang terdapat dalam tubuh dapat berupa enzim seperti fosfolipase, protease, serta enzim yang dapat memperbaiki susunan DNA. Antioksidan yang tersedia dalam tubuh tidak sebanding dengan banyaknya radikal bebas yang mungkin masuk ke dalam tubuh. Oleh karena itu, untuk menangkap dan mencegah radikal bebas tersebut merusak sel-sel tubuh, diperlukan tambahan antioksidan dari luar tubuh (Syafiqoh, 2016). Mekanisme antioksidan dari probiotik dapat terjadi melalui pengikatan ROS, pengkelatan ion logam, penghambatan enzim, dan mengurangi serta menghambat aktivitas autooksidasi askorbat. Mekanisme lain juga bisa menjadi dasar efek antioksidan dari pemberian probiotik, yaitu tikus stres yang diberikan probiotik memiliki kadar enzim GSH (antioksidan enzim) yang stabil (Amaretti, et al., 2013). Pemberian probiotik pada tikus mampu menginduksi transkripsi gen yang terlibat dalam biosintesis glutathione (GSH) di mukosa usus (Lutgendorff, et al., 2009) dan meningkatkan sintesis glutathione dalam sel pankreas (Lutgendorff et al., 2008). Penelitian Syafiqoh (2016) melaporkan ekstrak kasar media kultur $L$. plantarum SK(5) memiliki aktivitas antioksidan.

Berdasarkan hasil uji post hoc Tuckey, pada kelompok perlakuan $\mathrm{K}$ - dan kelompok perlakuan $\mathrm{K}+$ nilai $p$-value $=0,006<p$-value $=0,05$ yang artinya terdapat perbedaan kadar glukosa darah yang signifikan. Kelompok perlakuan K-

\section{DAFTAR PUSTAKA}

American Diabetes Association (ADA). (2011). Diagnosis and Classification of Diabetes Mellitus. Diabetes Care. Jan;34 (Suppl 1): S62-S69.

Adewani, N. (2008). Pengaruh Pemberian Rebusan Kulit Kayu Duwet Terhadap Persentase Penurunan Kadar Glukosa kadar glukosa darah tikus berada pada kisaran normal sedangkan kelompok perlakuan $\mathrm{K}+$ kadar glukosa darah berada diatas normal karena induksi aloksan.

Kelompok perlakuan P1, P2, P3 tidak berbeda signifikan dengan kelompok perlakuan $\mathrm{K}+$ sebagai kontrol tikus sakit (Diabetes Mellitus) yang artinya tikus setelah diberi Lactobacillus plantarum isolat ASI sesuai dosis masing-masing kelompok perlakuan masih dalam kondisi Diabetes Mellitus. Hal ini dapat disebabkan karena variasi biologis hewan uji dan waktu terapi yang relatif singkat yaitu 7 hari.

Kelompok perlakuan P1, P2, P3 tidak berbeda signifikan dengan kelompok perlakuan K- sebagai kontrol tikus sehat yang artinya perlakuan dengan Lactobacillus plantarum isolat ASI sesuai dosis masing-masing kelompok perlakuan, memberikan hasil penurunan glukosa darah yang mendekati kadar glukosa tikus sehat.

Hal ini sesuai dengan pernyataan (Yun, Park and Kang, 2009) glukosa darah tikus yang diberi perlakuan dengan Lactobacillus BNR17 lebih rendah dari pada kelompok yang tidak diberikan perlakuan. Pemberian susu fermentasi Lactobacillus Casei sebagai terapi diabetes pada mencit dapat menurunkan kadar glukosa darah (Sari et al., 2017). Lactobacillus plantarum sk(5) asal bekasam memiliki efek antidiabetes dan tidak bersifat toksik selama 14 hari pemberian dengan dosis yang sama (Syafiqoh, 2016).

Perlakuan antar kelompok P1, P2, P3 dengan hasil tidak terdapat perbedaan bermakna antar 3 kelompok perlakuan tersebut walaupun dengan dosis yang berbeda. Ke 3 dosis pemberian tersebut mempunyai efek penurunan glukosa yang setara. Sehingga dosis pemberian 1 kali sehari merupakan dosis yang baik dalam menurunkan glukosa darah secara efisien.

\section{SIMPULAN}

Lactobacillus plantarum isolat ASI mempunyai aktivitas antidiabetes terhadap tikus galur wistar dengan dosis pemberian 1 kali sehari.

Darah Pada Tikus Putih. [Skripsi]. Yogyakarta: Universitas Muhammadiyah Yogyakarta.

Alsayadi, M., et al. (2014). Evaluation of AntiHyperglycemic and Anti-Hyperlipidemic Activities of Water Kefir as Probiotic on Streptozotocin-Induced Diabetic Wistar 
Rats', Journal of Diabetes Mellitus, 04(02), pp. 85-95. doi: 10.4236/jdm.2014.42015.

Amaretti A, di Nunzio M, Pompei A, Raimondi S, Rossi M, Bordoni A. (2013). Antioxidant properties of potentially probiotic bacteria: in vitro and in vivo activities. Appl Microbiol Biotechnol. 97(2):809-817.

Atlas, I. D. (2015). International Diabetes Federation. ISBN 2930229853, 7.

Chen, P. et al. (2014). Screening for potential new probiotic based on probiotic properties and $\alpha$-glucosidase inhibitory activity. Food Control. Elsevier Ltd, 35(1), pp. 65-72. doi: 10.1016/j.foodcont.2013.06.027.

Dewi, S.S \& Herlisa, A. (2015). Aktivitas Lactobacillus plantarum Isolat ASI Terhadap Imunoglobulin (IgA , IgG) pada Tikus Wistar Model Sepsis. The 2nd University Research Coloquium 2015. ISSN 2407-9189.

Dewi, S. S. and Ariyadi, T. (2017) Profil Protein Bakteri Asam Laktat Isolat Air Susu Ibu. Prosiding Seminar Nasional \& Internasional. Semarang: Universitas Muhammadiyah Semarang.

Djide M.N, Wahyudin E. (2008). Isolasi Bakteri Asam Laktat dari Air Susu Ibu, dan Potensinya dalam penurunan kadar kolesterol secara in vitro. Majalah Farmasi dan Farmakologi, Vol. 12, No. 3Nopember 2008 (ISSN:1410- 7031).

Fadhilah, A.N., Hafsan,. Famawati, N. (2015) Penurunan Kadar Kolesterol Oleh Bakteri Asam Laktat Asal Dangke Secara In Vitro. Prosiding Seminar Nasional Mikrobiologi Kesehatan Dan Lingkungan. Makassar. 29 Januari 2015. ISBN 978-602-722450-6.

Fatmawati. (2013). Potensi Isolat Bakteri Asam Laktat Yang Diisolasi dari Dangke Sebagai Probiotik Berdasarkan Toleransi $\mathrm{pH}$ Rendah. [Skripsi]. Makassar: Fakultas Sains dan Teknologi, UIN Alauddin Makassar.

Gao, H. et al. (2007). Inhibitory effect on $\alpha$ glucosidase by the fruits of Terminalia chebula Retz, Food Chemistry, 105(2), pp. 628-634.

10.1016/j.foodchem.2007.04.023

Jain, S. and Saraf, S. (2010) Type 2 diabetes mellitus-Its global prevalence and therapeutic strategies. Diabetes and Metabolic Syndrome: Clinical Research and Reviews. Diabetes India, 4(1), pp. 4856. doi: 10.1016/j.dsx.2008.04.011.
Januarsyah,T. (2007). Kajian Aktivitas Hambat Bakteriosin dari Bakteri Asam Laktat Galur SCG 1223. [Skripsi]. Bogor: Fakultas Teknologi Pertanian Institut Pertanian Bogor.

Lutgendorff F, Trulsson LM, van Minnen LP, Rijkers GT, Timmerman HM, Franzen LE, Gooszen HG, Akkermans LMA, Soderholm JD. (2008). Probiotics enhance pancreatic glutathione biosynthesis and reduce oxidative stress in experimental acute pancreatitis. Am $J$ Physiol Gastrointest Liver Physiol. 295:G1111G1121.

Lutgendorff F, Nijmeijer RM, Sandstrom PA, Trulsson LM, Magnusson KE, Timmerman HM, van Minnen LP, Rijkers GT, Gooszen HG, Akkermans LA, Soderholm JD. (2009). Probiotics prevent intestinal barrier dysfunction in acute pancreatitis in rats via induction of ileal mucosal glutathione biosynthesis. PLOS ONE. 4(2):e4512.

Lye, H. S. et al. (2009). The improvement of hypertension by probiotics: Effects on cholesterol, diabetes, renin, and phytoestrogens. International Journal of Molecular Sciences, 10(9), pp. 3755-3775. doi: 10.3390/ijms10093755.

Malik, I. M., Nasrul, E. and Asterina. (2014) 'Hubungan Hiperglikemia dengan Prothrombin Time pada Mencit (Mus musculus) yang Diinduksi Aloksan', Jurnal Kesehatan Andalas, 4(1), pp. 182188.

Marianne et al. (2014). Antidiabetic Activity of Leaves Ethanol Extract Chromolaena odorata (L.) R.M. King on Induced Male Mice with Alloxan Monohydrate. Jurnal Natural, 14(1), pp. 1-4. doi: 10.24815/jn.v14i1.1382.

Panwar, H. et al. (2014). Lactobacillus strains isolated from infant faeces possess potent inhibitory activity against intestinal alphaand beta-glucosidases suggesting antidiabetic potential. European Journal of Nutrition, 53(7), pp. 1465-1474. doi: 10.1007/s00394-013-0649-9.

Purwanti, H. S. (2004). Konsep penerapan ASI eksklusif. Jakarta: EGC.

Rahayu, E. S. (2001). Potensi dan peranan prebiotik dan probiotik dalam makanan sehat. Seminar Prebiotik, Probiotik dan Makanan Sehat. Fakultas Biologi Universitas Atmajaya. Yogyakarta.

Ramchandran, L. and Shah, N. P. (2008). Proteolytic profiles and angiotensin-I converting enzyme and $\alpha$-glucosidase 
inhibitory activities of selected lactic acid bacteria. Journal of Food Science, 73(2), pp. $\quad 75-81$. doi: $10.1111 / \mathrm{j} .1750$ 3841.2007.00643.x.

Sari, P. P., et al. (2017). Lactobacillus casei Fermented Milk as a Treatment for Diabetes in Mice (Mus musculus). Jurnal Medika VeterinariaA \& A (Banda Aceh), 11(1), pp. 15-19. doi: 10.21157/j.med.vet..v11i1.4088.

Salminen, S. \& A. V. Wright. (2004). Lactic Acid Bacteria. Microbiology and Functional Aspects. 2nd Edition, Revised and Expanded. Marcell Dekker, Inc., New York.

Subroto, A. (2006). Ramuan Herbal untuk Diabetes Melitus. Depok: Penebar Swadaya.

Setianingsih, S. (2010). Kajian Senyawa Antimikroba Bakteri Asam Laktat Homofermentaatif Isolat ASI. Journal of Chemical Information and Modeling. doi: 10.1017/CBO9781107415324.004.

Syafiqoh, N. (2016). Aktivitas Antioksidan dan Efek Antidiabetes Probiotik Lactobacillus plantarum SK(5) Asal Bekasam. [Tesis]. Bogor: Program Studi Mikrobiologi,
Sekolah Pascasarjana, Institut Pertanian Bogor.

Szkudelski, T. (2001). The mechanism of alloxan and streptozotocin action in B cells of the rat pancreas. Physiological Research, 50(6), pp. 537-546.

Walde, S.S., Dohle, C., Schott-Ohly, P., Gleichmann, H. (2002). Molecular target structures in alloxan-induced diabetes in mice. Life Sciences, 71, 1681-1694.

World Health Organization. (2016). Diabetes Fakta dan Angka. 26 November 2018. http://www.searo.who.int/indonesia/topics/ 8-whd2016-diabetes-facts-andnumbersindonesian.pdf.

Yun, S. I., Park, H. O. and Kang, J. H. (2009) Effect of Lactobacillus gasseri BNR17 on blood glucose levels and body weight in a mouse model of type 2 diabetes. Journal of Applied Microbiology, 107(5), pp. 1681$1686 . \quad$ doi: 10.1111/j.13652672.2009.04350.x.

Zhang Y, Zhang H. (2013). Microbiota associated with type 2 diabetes and its related complications. Food Sci Hum Well. 2:167-172. 